\title{
Application Load Balancing With Nth Method Multiple Gateway Internet Networks
}

\author{
Rasna*1, Ahmad Ashari $^{2}$ \\ ${ }^{1}$ Master Program of Computer Science; FMIPA UGM, Yogyakarta \\ ${ }^{2}$ Department of Computer Science and Electronics, FMIPA UGM, Yogyakarta \\ e-mail:*1'rasna@mail.ugm.ac.id, ${ }^{2}$ ashari@ugm.ac.id
}

\begin{abstract}
Abstrak
Salah satu kontribusi teknologi untuk meningkatkan kestabilan koneksi dalam suatu jaringan adalah dengan menggunakan tiga Internet Service Provider (ISP) dan menjadikan mikrotik sebagai load balance. Load balance mempunyai beberapa metode seperti per connection classifier (PCC) dan Nth. Namun PCC memiliki kekurangan dan kelebihan. Kekurangan PCC memungkinkan terjadinya overload di salah satu jalur ISP sehingga terjadi ketidak seimbangan penggunaan bandwidth.

Penelitian ini menerapkan Mikrotik dengan metode load balancing Nth pada jaringan internet yang memiliki tiga line gateway yang melalui router. Sehingga diharapkan beban pada tiga line Internet Service Provider (ISP) dapat berjalan dengan efektif. Hasil penelitian penerapan load balancing dengan metode Nth pada jaringan internet multiple gateway di Kantor Bupati Kabupaten Jayapura adalah terdapat perbandingan kualitas koneksi dari sebelum dan sesudah implementasi load balancing. Tx/Rx pada masing-masing ISP dan LAN menunjukkan throughput yang masuk sudah memiliki rata-rata nilai yang sama yaitu rata-rata yang didapatkan receiver (Rx) ISP-A adalah 34,75 Mbps, Rx ISP-B adalah 30,12 Mbps, Rx ISP$C$ adalah 7,17 Mbps dan transmitter (Tx) LAN adalah 72,03 Mbps. Penggunaan mekanisme load balancing Nth pada masing-masing ISP lebih optimal dibandingkan dengan sebelum penggunaan load balancing Nth, dan pada perolehan throughput yang telah menggunakan load balancing sudah seimbang diantara ketiga ISP.
\end{abstract}

Kata kunci-Load balance, Nth, PCC, gateway, mikrotik

\begin{abstract}
One contribution of technology to improve the stability of connections in a network is to use three Internet Service Providers (ISP) and make the proxy as load balance. Load balance has several methods such as per connection classifier (PCC) and Nth. But PCC has advantages and disadvantages. PCC deficiency allows overload in one ISP channel so that there is an imbalance in bandwidth usage.

The results of the study on the implementation of load balancing using the Nth method on multiple gateway internet networks in the Jayapura District Head Office is that there is a comparison of the quality of connections from before and after load balancing implementation. Tx/Rx at each ISP and LAN show the incoming throughput already has the same average value, that is, the average obtained by the ISP-A (Rx) receiver is $34.75 \mathrm{Mbps}$, ISP-B Rx is $30.12 \mathrm{Mbps}$, ISP-C Rx is $7.17 \mathrm{Mbps}$ and LAN transmitter (Tx) is $72.03 \mathrm{Mbps}$. The use of the Nth load balancing mechanism in each ISP is more optimal than before the use of load balancing Nth, and the acquisition of throughput that has used load balancing is balanced between the three ISP.
\end{abstract}

Keywords — Load balance, Nth, PCC, gateway, Mikrotik

Received Sept 24 $4^{\text {th }}$ 2018; Revised Feb 27 $7^{\text {th }}$ 2019; Accepted April 28 ${ }^{\text {th }}, 2019$ 


\section{INTRODUCTION}

Load balancing is an innovation used to overcome the burden of network capacity with users, and additional networks [1]. Load balancing can be applied to HTTP servers, proxies, databases, and gateways. In the load balancing process, there are four methods that can be applied using Mikrotik, one of which is the Nth method. The Nth method is known as the load balancing distribution method which is the development of the round robin load balancing method. The Nth method can work with principles per packet load balance or per connection load balance. The Nth technique is known as the round robin method in dividing the load. It divides evenly distributed data packets on each gateway. Existing packages will be grouped into several groups in a row, ie package 1 enters group 1, package 2 enters group 2, etc. Later each group will be issued via the exit interface which is available sequentially, group 1 will exit through interface 1, group 2 will exit through interface 2, etc. With load balancing Nth, it can be a very effective technology solution for utilizing internet bandwidth without having to occur inequality [2].

The Jayapura District Regent's Office as a Regional Government Institution that has internet services utilizes wireless technology as a means of improving services. The importance of internet access speed as a means of communication, the use of internet access needs to be regulated so that it is convenient for its users. Internet access speed will certainly relate to the amount of bandwidth available in a network. The importance of the speed of internet access has made the Jayapura District Office use three Internet Service Providers. To get maximum internet access speed, load balancing settings on bandwidth are needed so that internet traffic in a network does not experience overload.

To minimize the occurrence of these problems and keep the internet network connection stable and smooth, the three connection lines are connected to a device, the router, the Load Balancing technique is applied to the router [3]. Mikrotik is one router that can implement load balancing techniques. This study applies a proxy with the nth load balancing method on an internet network that has three line gateways through a router. The load balancing mechanism, which is the proxy, will mark packets that want to access the internet, then equalize the load on the three ISPs that are distributed through LAN and wifi cable networks

[4]. Then choose which ISP path to pass. So it is expected that the load on the three ISP lines can run effectively.

In research [5] analyze slow internet access due to other users who download by comparing the Simple Queues and Queues Tree methods. While in research [6] to overcome the company's loss problem because there is no even distribution of traffic load to the router using NDLC and Load Balancing Nth methods. Research [7] analyze the comparison of PCC, Nth and ECMP load balancing implementation.

\section{METHODS}

This study uses the Nth load balancing method. The tests carried out in this study are downloading, uploading and streaming video before and after load balancing is applied. To find out the quality of the internet network that has been loaded balance, Quality of Service is tested with parameters of delay, throughput, jitter, and packet loss. Quality of Service is a method of measuring how well the network is installed and is also an attempt to define the characteristics and properties of service [8]. The test results will be analyzed to see the of applying influence load balancing.

\subsection{Research material}

Research material plays an important role as a reference in the implementation and testing of the systems needed for the results analysis phase. The collection of data needed as material for this research was obtained from sources namely literature studies such as papers,

IJCCS Vol. 13, No. 2, April 2019: 159-168 
reference books, and related research results. From these data then an understanding of the system needs that are built and their implementation is obtained.

\subsection{Research tool}

The tool used in this study consisted of hardware and software. From the needs analysis conducted, it can be identified the need for hardware installed in the internet network at the Jayapura District Head Office as seen in Table 1.

Table 1 Equipment installed in the Jayapura District Head Office

\begin{tabular}{|l|l|}
\hline No & Installed device \\
\hline 1 & Radio Rocket $\mathrm{MS}$ \\
\hline 2 & APC Arrester \\
\hline 3 & Router RB 750 \\
\hline 4 & IP phone \\
\hline 5 & Switch Tplink 16 port \\
\hline 6 & Wifi Tplink \\
\hline 7 & 1 line ISP PSN with capacity 7 Mbps \\
\hline 8 & 1 line ISP ASTINet with capacity $35 \mathrm{Mbps}$ \\
\hline 9 & 1 line ISP IndiHome with capacity $30 \mathrm{Mbps}$ \\
\hline
\end{tabular}

The Nth method which literally means that $\mathrm{N}$ is a number of integers $(0 . .15)$ and thus the size of the number. Nth is a method that uses matching algorithms for a number of numbers, each of which is given integer value, with the $\mathrm{x}$ package received by the standard rules in the method. A number of these numbers indicate how many servers will be implemented in the load balancing technique. Then one of the 16 available counters can be used to calculate each packet sent and received [9].

The software requirement used to help this research is MikroTik RouterOS TM which is the operating system to build a router, Microsoft Windows is the operating system for admin and client and Winbox Mikrotik is a software to access the Mikrotik Router.

\subsection{Research flow} found in Figure 1.

The research work will be carried out in accordance with the research flow chart

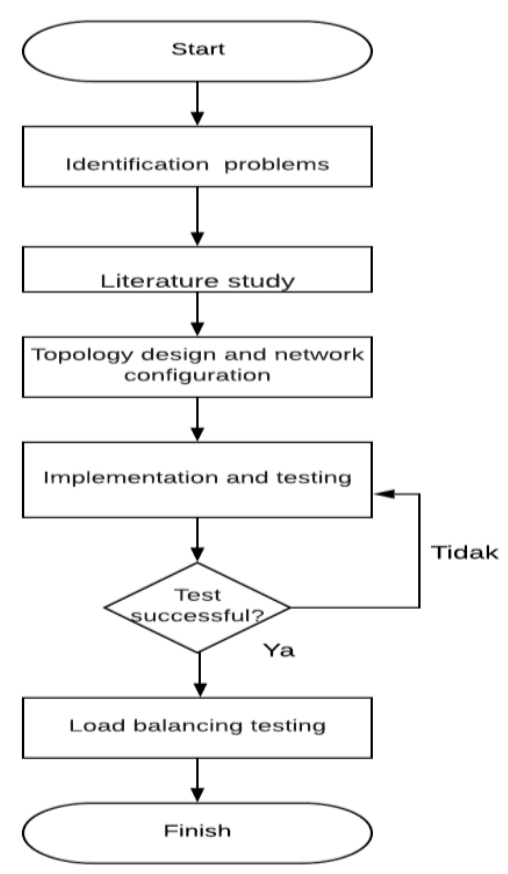

Figure 1 Research Flow Chart 


\subsection{Identification of problems}

The problem identification stage is the stage to determine the background of this research. The problem identification stage is done by examining cases on a computer network system that is related to the use of Nth load balancing techniques as a solution to the problems encountered. After finishing reviewing several cases, a list of problems is then sorted according to the level of sensitivity of the problem.

\subsection{Reference library}

After the problem identification is complete, the next step is to conduct a literature study. The literature study in question is to study and review various literature in the form of books, journals, theses, articles, and online media related to load balancing. In addition, the literature is also used as a reference source of research references. By collecting and learning many references, it is hoped that the research conducted can produce the best solution that can be done to solve existing problems.

\subsection{Topology design and network system configuration}

After a literature study, the next thing to do is to design and create the network topology used in this study. Topology is created and configured according to the research material that has been obtained. The purpose of topology design and network system configuration is to facilitate when load balancing methods are implemented and tested as research objects.

\subsection{Research object}

The internet network infrastructure in the Jayapura District Office is shown in Figure 2. The internet network is built with a combination of wireless connection, fiber optic, and LAN using TVRI towers as communication relay centers at several points (Sentani, Sentani Timur, Waibu, Ebungfau, and Sentani Barat) and for unattainable points, the TVRI relay tower is connected via satellite and distributed using a wireless connection.

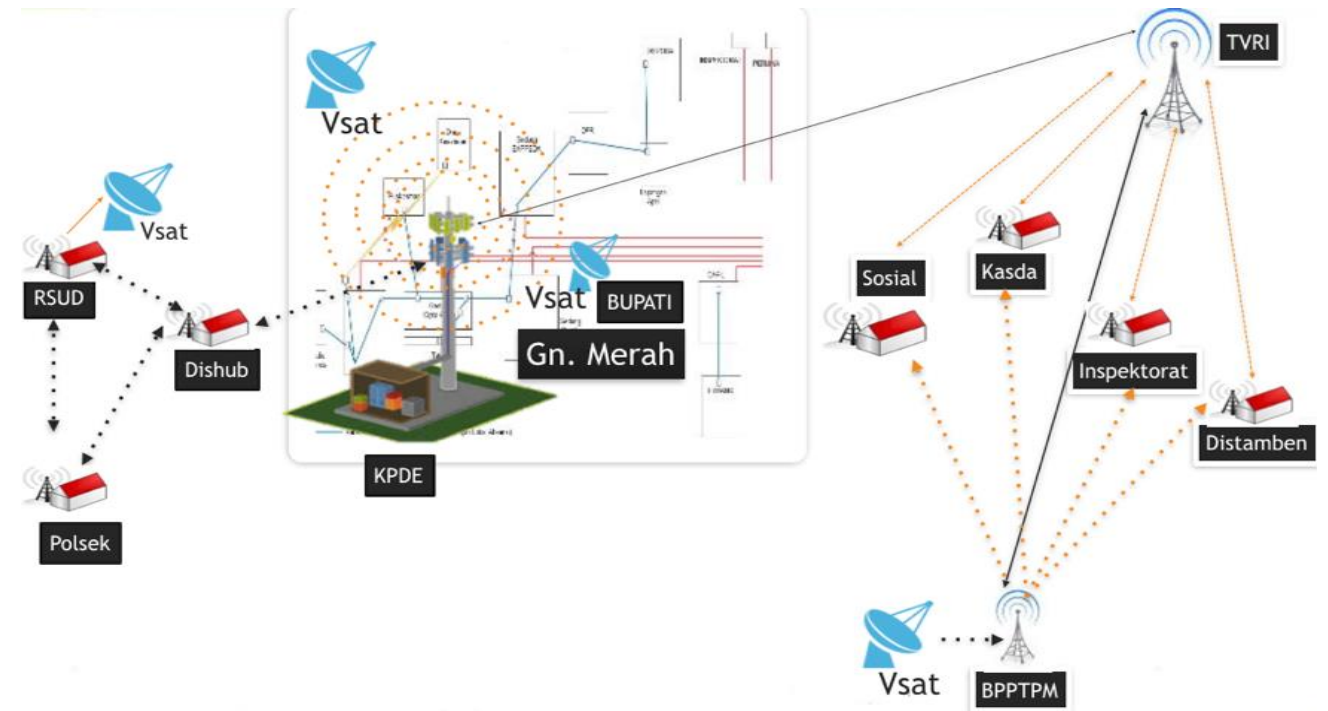

Figure 2 Internet network infrastructure in the Jayapura District Head Office

The study was conducted on three internet gateway lines, namely PT. Telkom (ASTINET), IndiHome (Telkom) and PT. Pasifik Satelit Nusantara (PSN). The three line gateways are in the KPDE building (Office of Communication and Information). The research conducted was analyzing the performance of the three lines, both in terms of Quality of Service, uploading and downloading.

IJCCS Vol. 13, No. 2, April 2019 : 159-168 


\subsection{System design}

The test will involve internet users, namely all employees in the Jayapura District Head Office. Research using Nth load balancing method by combining three internet connections from three Internet Service Providers is done in order to add internet speed and reduce traffic load on one line. The system is carried out with a traffic balancing system for user requests or traffic balancers. The system will reduce the router workload so that the network conditions are relatively stable. All internet requests from users will enter the router that has been configured with the nth Load balancing method. On the router, there will be connection marking so that the connection path can be passed through the first gateway, the second gateway, or through the third gateway. After connection marking occurs, routing will occur into the routing table, so that the three available gateways can be used simultaneously.

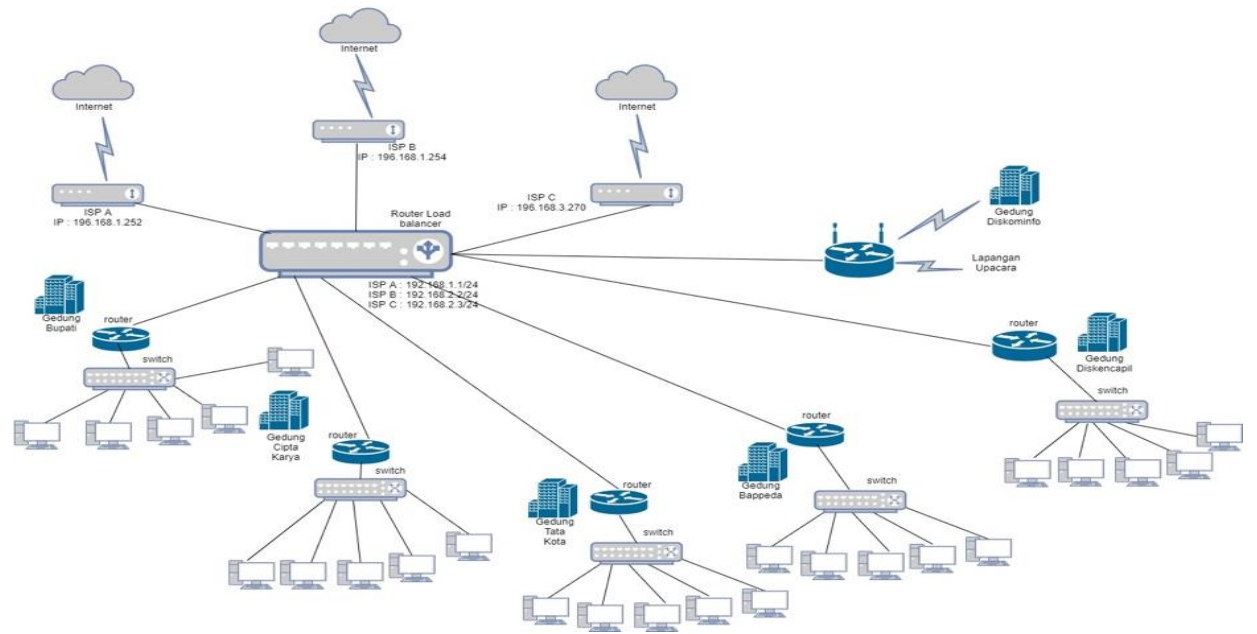

Figure 3 Load balancing design at the Jayapura District Head Office

Figure 3 is the Nth load balancing design in the Jayapura District Head Office which has three gateways for internet connection. Based on the Nth mechanism, for the topology above each traffic/data packet that passes will be divided into 1, 2, and 3. Then for the ISP-A link will be used for packet 1, the ISP-B link will be used for packet 2, and link ISP-C will be used for packet path 3 . The client on the network will have one gateway, and the gateway will determine the packet will pass through the ISP line. The load balancing is implemented in a series consisting of every and packet and is realized in an integer series. In the load balancing method, the incoming data packet is marked as a variable $\mathrm{n}$ in the integer data type. Load balancing applied in this study on 3 internet data lines (connections), which means that $\mathrm{n}$ will be worth 3. Then, integer values form queues 3.1, 3.2 and 3.3.

\section{RESULTS AND DISCUSSION}

Load Balancing is the ability to reduce the load from a process to an application to several different systems so as to increase processing capability on incoming requests. Load Balancing will send some processing from request to a system to other systems that will be handled simultaneously. With load balancing has the advantage of reducing the amount of processing that must be carried out by the main receiving server, allowing the receiving server to handle more requests from the device that processes all loads.

\subsection{Network configuration}

Interface initialization is done by giving names to each interface according to its function. The commands performed are as follows. Mikrotik initialization commands are shown in Figure 4. 


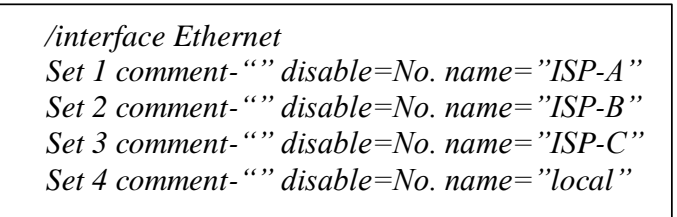

Figure 4 Initialization interface

\subsection{IP Address Assignment}

At this stage the IP address is given at each interface, both on the proxy, and from the client side. To assign an IP address to the router is shown in Figure 5.

lip address

Add address $=192.168 .1 .1 / 24$ network=192.168.1.0 broadcast $=192.168 .1 .1 / 24$

network $=192.168 .1$ broadcast $=192.168 .1 .255$ comment $=$ " "' $\backslash$ disabled $=$ No. interface $=I S P-A$

Add address $=192.168 .1 .2 / 24$ network=192.168.1.0 broadcast $=192.168 .1 .255$ comment $=$ "” $\backslash$ disabled $=$ No. interface $=I S P-B$

Add address $=192.168 .1 .3 / 24$ network $=192.168 .1 .0 \mathrm{\vee broadcast}=192.168 .1 .255$ comment $=$ "”, $\backslash$ disabled $=$ No interface $=I S P-C$

Add address $=192.168 .1 .4 / 24$ network=192.168.1.0 broadcast $=192.168 .1 .255$ comment $=$ "' $\backslash$ disabled $=$ No. interface $=$ lokal

Figure 5 Giving IP Address

\subsection{Client's IP Address Assignment}

In Figure 6 shows the marking form command before the data packet enters into the prerouting policy, and shows how to create an address in the Nth and its merge with the mark function. Where the "LOCAL" interface with destination port 80 is given a connection mark with the name "lb_1" with the value nth is 3.1 which means the value of every $=3$ packet $=1$ value.

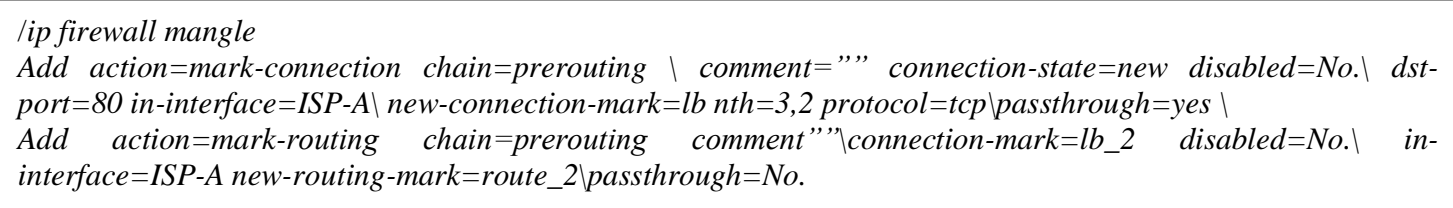

\section{Figure 6 Giving the IP Address of the client}

\subsection{Routing configuration}

To forward the marked package in the mangle process, a new rule is created on the routing table so that it can pass the data packet to the ISP gateway that matches the marketing package created at the mangle stage. The routing configuration command is shown in Figure 7.

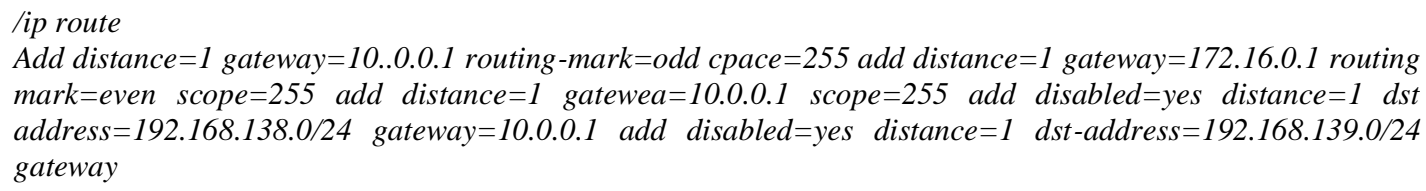

Figure 7 Routing configuration

The next command is to add a gateway without routing mark, and this gateway is used as a default gateway for all traffic that is not through load balancing. The above command is used to define the gateway path used for each packet that will exit the local network. In this code, every packet that has an odd mark will be passed through the next-hop gateway 10.0.0.1 (ISP-A). Whereas for packages that have mark event will be passed through the next-hop gateway 172.16.0.1 (ISP-B).

\subsection{NAT configuration}

The last configuration in Nth load balancing is NAT or in Mikrotik better known as a masquerade. This serves to be able to change the packet source address, namely the client that 
has a private IP address so that it can be recognized on the internet by translating it into a public IP address. The NAT configuration command is shown in Figure 8.

lip firewall nat

Add action $=$ masquerade chain $=$ srcnat comment $=$ "' $\backslash$ disabled $=$ No. out-interface $=I S P-A$

Add action $=$ masquerade chain $=$ srcnat comment $=$ "' '’ $\backslash$ disabled $=$ No. out-interface $=I S P-B$

Add action $=$ masquerade chain $=$ srcnat comment $=$ "' $\backslash$ disabled $=$ No. out-interface $=I S P-C$

\section{Figure 8 NAT configuration}

The above command shows the configuration of the Nth load balancing to do the NAT process for each packet header that comes out of the router interface, namely the ISP-A interface, ISP-B interface, and ISP-C interface.

\subsection{Testing before load balancing Nth}

The test was carried out with five trials on the ISP-A, ISP-B and ISP-C servers by looking at the results of the download, upload rate and ping time before load balancing was carried out. Testing is done using the speed test application. The test results can be seen in Table 2.

Table 2 Test results before load balancing

\begin{tabular}{|c|c|c|c|c|c|c|c|c|}
\hline \multicolumn{2}{|c|}{ ISP-A } & \multicolumn{2}{c|}{ ISP-B } & \multicolumn{2}{c|}{ ISP-C } \\
\hline Ping & Download & Upload & Ping & Download & Upload & Ping & Download & Upload \\
\hline $\begin{array}{c}160 \\
\mathrm{~ms}\end{array}$ & $5,95 \mathrm{Mbps}$ & $\begin{array}{c}29,94 \\
\text { Mbps }\end{array}$ & $\begin{array}{c}120 \\
\mathrm{~ms}\end{array}$ & $1,40 \mathrm{Mbps}$ & $\begin{array}{c}28,50 \\
\mathrm{Mbps}\end{array}$ & $\begin{array}{c}174 \\
\mathrm{~ms}\end{array}$ & $5,57 \mathrm{Mbps}$ & $1,73 \mathrm{Mbps}$ \\
\hline $\begin{array}{c}155 \\
\mathrm{~ms}\end{array}$ & $9,32 \mathrm{Mbps}$ & $\begin{array}{c}20,05 \\
\mathrm{Mbps}\end{array}$ & $\begin{array}{c}125 \\
\mathrm{~ms}\end{array}$ & $7,56 \mathrm{Mbps}$ & $\begin{array}{c}21,43 \\
\mathrm{Mbps}\end{array}$ & $\begin{array}{c}174 \\
\mathrm{~ms}\end{array}$ & $6,32 \mathrm{Mbps}$ & $1,60 \mathrm{Mbps}$ \\
\hline $\begin{array}{c}109 \\
\mathrm{~ms}\end{array}$ & $4,98 \mathrm{Mbps}$ & $\begin{array}{c}31,71 \\
\mathrm{Mbps}\end{array}$ & $\begin{array}{c}130 \\
\mathrm{~ms}\end{array}$ & $2,63 \mathrm{Mbps}$ & $\begin{array}{l}27,94 \\
\mathrm{Mbps}\end{array}$ & $\begin{array}{l}165 \\
\mathrm{~ms}\end{array}$ & $6,13 \mathrm{Mbps}$ & $1,17 \mathrm{Mbps}$ \\
\hline $\begin{array}{c}167 \\
\mathrm{~ms}\end{array}$ & $4,18 \mathrm{Mbps}$ & $\begin{array}{c}30,73 \\
\mathrm{Mbps}\end{array}$ & $\begin{array}{c}128 \\
\mathrm{~ms}\end{array}$ & $1,39 \mathrm{Mbps}$ & $\begin{array}{l}28,16 \\
\mathrm{Mbps}\end{array}$ & $\begin{array}{c}165 \\
\mathrm{~ms}\end{array}$ & $5,24 \mathrm{Mbps}$ & $1,10 \mathrm{Mbps}$ \\
\hline $\begin{array}{c}159 \\
\mathrm{~ms}\end{array}$ & $3,21 \mathrm{Mbps}$ & $\begin{array}{c}32,24 \\
\mathrm{Mbps}\end{array}$ & $\begin{array}{c}136 \\
\mathrm{~ms}\end{array}$ & $9,54 \mathrm{Mbps}$ & $\begin{array}{l}20,32 \\
\mathrm{Mbps}\end{array}$ & $\begin{array}{c}164 \\
\mathrm{~ms}\end{array}$ & $5,67 \mathrm{Mbps}$ & $1,96 \mathrm{Mbps}$ \\
\hline
\end{tabular}

\subsection{Testing after load balancing Nth}

From the results of the tests that have been carried out as in Table 3 can be seen the comparison of the quality of the connection from before and after the implementation of load balancing. The test shows that on the download side is $39.23 \mathrm{Mbps}$ and upload is $65.06 \mathrm{Mbps}$, ping is an average of $38 \mathrm{~ms}$. Furthermore, the average download was $36.03 \mathrm{Mbps}$, uploading $67.90 \mathrm{Mbps}$ and ping on average was $37 \mathrm{~ms}$. Based on Table 3 shows the quality of internet connections has changed a lot on ping data, upload data, and downloads. On download, testing can be seen the speed increases when the load balancing system. Connection quality can be seen from the size of the roundtrip and the number of lost packages. The smaller these two numbers, the better the quality of the connection. The ping utility in Table 3 shows small results. This can be explained that Nth load balancing can balance the connections between the three ISP.

Table 3 Test results The Nth method after load balancing

\begin{tabular}{|c|c|c|c|}
\hline Testing & Ping & Download & Upload \\
\hline 1 & $38 \mathrm{~ms}$ & $36,40 \mathrm{Mbps}$ & $69,01 \mathrm{Mbps}$ \\
\hline 2 & $38 \mathrm{~ms}$ & $39,23 \mathrm{Mbps}$ & $65,06 \mathrm{Mbps}$ \\
\hline 3 & $37 \mathrm{~ms}$ & $35,17 \mathrm{Mbps}$ & $67,81 \mathrm{Mbps}$ \\
\hline 4 & $37 \mathrm{~ms}$ & $33,73 \mathrm{Mbps}$ & $69,84 \mathrm{Mbps}$ \\
\hline 5 & $38 \mathrm{~ms}$ & $35,63 \mathrm{Mbps}$ & $67,79 \mathrm{Mbps}$ \\
\hline
\end{tabular}

\subsection{Test results for the deployment of Packet Load Balancing Nth}

Parameters tested on the balance of connections at each ISP gateway Nth load balancing is the average spread of packet transmitted (Tx/upload) from each gateway. In Table 4 it can be seen that Nth load balancing has successfully spread the same packet on all three interfaces. This result shows that the Nth load balancing method can divide the transmitted spread evenly at each gateway. 
Table 4 The results of testing the spread of packet load balancing

\begin{tabular}{|c|c|c|c|c|}
\hline Testing & ISP-A(Rx) & ISP-B(Rx) & ISP-C (Rx) & LAN (Tx) \\
\hline 1 & $34,70 \mathrm{Mbps}$ & $29,90 \mathrm{Mbps}$ & $7,93 \mathrm{Mbps}$ & $72,53 \mathrm{Mbps}$ \\
\hline 2 & $35,02 \mathrm{Mbps}$ & $30,19 \mathrm{Mbps}$ & $7,40 \mathrm{Mbps}$ & $72,61 \mathrm{Mbps}$ \\
\hline 3 & $34,33 \mathrm{Mbps}$ & $29,97 \mathrm{Mbps}$ & $7,30 \mathrm{Mbps}$ & $71,60 \mathrm{Mbps}$ \\
\hline 4 & $34,67 \mathrm{Mbps}$ & $30,06 \mathrm{Mbps}$ & $7,10 \mathrm{Mbps}$ & $71,83 \mathrm{Mbps}$ \\
\hline 5 & $35,07 \mathrm{Mbps}$ & $30,10 \mathrm{Mbps}$ & $7,00 \mathrm{Mbps}$ & $72,17 \mathrm{Mbps}$ \\
\hline 6 & $35,01 \mathrm{Mbps}$ & $29,99 \mathrm{Mbps}$ & $6,20 \mathrm{Mbps}$ & $71,20 \mathrm{Mbps}$ \\
\hline 7 & $34,34 \mathrm{Mbps}$ & $32,09 \mathrm{Mbps}$ & $7,10 \mathrm{Mbps}$ & $73,53 \mathrm{Mbps}$ \\
\hline 8 & $35,01 \mathrm{Mbps}$ & $30,50 \mathrm{Mbps}$ & $7,22 \mathrm{Mbps}$ & $72,73 \mathrm{Mbps}$ \\
\hline Average & $34,75 \mathrm{Mbps}$ & $30,12 \mathrm{Mbps}$ & $7,17 \mathrm{Mbps}$ & $72,03 \mathrm{Mbps}$ \\
\hline
\end{tabular}

\subsection{Throughput testing}

In the process of measuring throughput, testing is carried out for 4 days, which starts on Monday, 11 October 2018 to 14 October 2018. The testing process is carried out during rush hour, which is the range between 08.00-16.00 hours. The throughput value is described by the average throughput. Throughput is based on testing using the speed test application. The test results are shown in Table 5

Table 5 Results of throughput testing

\begin{tabular}{|c|c|c|c|c|}
\hline \multirow[b]{2}{*}{ Date } & \multirow{2}{*}{ Time(WIT) } & \multirow{2}{*}{$\begin{array}{c}\text { Average } \\
\text { Throughput }\end{array}$} & \multicolumn{2}{|c|}{ Information } \\
\hline & & & Index & Category \\
\hline \multirow{5}{*}{11 October 2018} & 08.00 & 80.27 Mbps & 3 & Good \\
\hline & 10.00 & $80.89 \mathrm{Mbps}$ & 3 & Good \\
\hline & 12.00 & $82.76 \mathrm{Mbps}$ & 2 & Good \\
\hline & 14.00 & $80.89 \mathrm{Mbps}$ & 2 & Good \\
\hline & 16.00 & $83.45 \mathrm{Mbps}$ & 2 & Good \\
\hline \multirow{5}{*}{12 October 2018} & 08.00 & $81.5 \mathrm{Mbps}$ & 3 & Good \\
\hline & 10.00 & $82.5 \mathrm{Mbps}$ & 3 & Good \\
\hline & 12.00 & 79.2 Mbps & 3 & Good \\
\hline & 14.00 & 79.9 Mbps & 2 & Good \\
\hline & 16.00 & $84.2 \mathrm{Mbps}$ & 2 & Good \\
\hline \multirow{5}{*}{13 October 2018} & 08.00 & 89.4 Mbps & 3 & Good \\
\hline & 10.00 & 85.3 Mbps & 3 & Good \\
\hline & 12.00 & $80.2 \mathrm{Mbps}$ & 3 & Good \\
\hline & 14.00 & 89.9 Mbps & 3 & Good \\
\hline & 16.00 & 89.9 Mbps & 3 & Good \\
\hline \multirow[t]{5}{*}{14 October 2018} & 08.00 & $96.3 \mathrm{Mbps}$ & 3 & Good \\
\hline & 10.00 & 92.4 Mbps & 3 & Good \\
\hline & 12.00 & $80.9 \mathrm{Mbps}$ & 2 & Good \\
\hline & 14.00 & $76.3 \mathrm{Mbps}$ & 2 & Good \\
\hline & 16.00 & $70.3 \mathrm{Mbps}$ & 2 & Good \\
\hline
\end{tabular}

Based on Table 5 the results of throughput measurements obtained for four days. The test results show that the average throughput has index 3, according to TIPHON standards is in a good category. The throughput monitoring results are displayed in four days, with a time variation between 08.00-16.00.

\subsection{Packet loss testing}

Packet loss testing uses tools NetTools when sending data packets from the client. The results of packet loss testing in Table 6 obtain an average of $0 \%$ with a very good category. From these values, it can be concluded that packet loss testing according to TIPHON standards is in a good category. 
Table 6 Results of testing Packet Loss

\begin{tabular}{|c|c|c|c|c|c|c|}
\hline \multirow{2}{*}{ Date } & \multirow{2}{*}{ Time (WIT) } & \multicolumn{3}{|c|}{ Average packet loss } & \multirow{2}{*}{ Index } & \multirow{2}{*}{ Category } \\
\hline & & ISP_A & ISP-B & ISP-C & & \\
\hline \multirow{5}{*}{$\begin{array}{c}11 \text { October } \\
2018\end{array}$} & 08.00 & 0 & 0 & 0 & 4 & Verv good \\
\hline & 10.00 & 0 & 0 & 0 & 4 & Verv good \\
\hline & 12.00 & 2 & 1 & 1 & 4 & Verv good \\
\hline & 14.00 & 0 & 0 & 0 & 4 & Verv good \\
\hline & 16.00 & 0 & 0 & 0 & 4 & Verv good \\
\hline \multirow{5}{*}{$\begin{array}{c}12 \text { October } \\
2018\end{array}$} & 08.00 & 0 & 0 & 0 & 4 & Verv good \\
\hline & 10.00 & 1 & 1 & 1 & 4 & Verv good \\
\hline & 12.00 & 0 & 0 & 0 & 4 & Verv good \\
\hline & 14.00 & 2 & 2 & 2 & 4 & Verv good \\
\hline & 16.00 & 0 & 0 & 0 & 4 & Very good \\
\hline \multirow{5}{*}{$\begin{array}{c}13 \text { October } \\
2018\end{array}$} & 08.00 & 0 & 0 & 0 & 4 & Verv good \\
\hline & 10.00 & 0 & 0 & 0 & 4 & Very good \\
\hline & 12.00 & 0 & 0 & 0 & 4 & Verv good \\
\hline & 14.00 & 1 & 1 & 1 & 4 & Very good \\
\hline & 16.00 & 0 & 0 & 0 & 4 & Verv good \\
\hline \multirow{5}{*}{$\begin{array}{c}14 \text { October } \\
2018\end{array}$} & 08.00 & 2 & 1 & 1 & 4 & Verv good \\
\hline & 10.00 & 1 & 1 & 1 & 4 & Verv good \\
\hline & 12.00 & 1 & 1 & 1 & 4 & Very good \\
\hline & 14.00 & 0 & 0 & 0 & 4 & Verv good \\
\hline & 16.00 & 0 & 0 & 0 & 4 & Very good \\
\hline
\end{tabular}

In Table 6 shows on 11 October 2018 at 08.00 to 16.00 the average packet loss at ISP-A, ISP-B and ISP-C ranged from 0-2\% with index 4 with a very good category. On October 12, 2018, at 08.00 to 16.00 the average packet loss at ISP-A, ISP-B, ISP-C ranged from $0-1 \%$ with very good category. Condition for the total number of lost packet losses, due to equipment damage and bad weather. The causes of packet loss can occur due to collisions or collisions between data on the network and this affects all lines.

\subsection{Delay Testing Results (latency)}

Based on the QoS value according to the TIPHON version as standardization, the latency category is a "very good" if the delay is $<150 \mathrm{~ms}$, "good" if the delay is $150 \mathrm{~ms}$ to $300 \mathrm{~ms}$, "moderate" if the delay is $>450 \mathrm{~ms}$. In Table 7, the results of testing delay (latency) can be seen. Data collection is carried out during working hours between 08.00 - 16.00 WIT for four days. Measurements are made from the router load balancer side, to monitor network response on each path. It appears that the average latency is $<150 \mathrm{~ms}$.

Table 7 Test results for a delay (latency)

\begin{tabular}{|c|c|c|c|c|c|c|c|}
\hline \multirow{2}{*}{ Date } & \multirow{2}{*}{ Time (WIT) } & \multicolumn{3}{|c|}{ Latency (ms) } & \multirow{2}{*}{$\begin{array}{l}\text { Average } \\
\text { latency }\end{array}$} & \multirow{2}{*}{ Index } & \multirow{2}{*}{ Category } \\
\hline & & ISP-A & ISP-B & ISP-C & & & \\
\hline \multirow{5}{*}{$\begin{array}{c}11 \\
\text { October } 2018\end{array}$} & 08.00 & 102 & 194 & 136 & 144 & 4 & Very good \\
\hline & 10.00 & 93 & 189 & 82 & 121 & 4 & Very good \\
\hline & 12.00 & 114 & 107 & 136 & 119 & 4 & Very good \\
\hline & 14.00 & 82 & 104 & 82 & 89 & 4 & Very good \\
\hline & 16.00 & 144 & 95 & 93 & 111 & 4 & Very good \\
\hline \multirow{5}{*}{$\begin{array}{c}12 \\
\text { October } 2018\end{array}$} & 08.00 & 78 & 76 & 77 & 77 & 4 & Very good \\
\hline & 10.00 & 158 & 143 & 87 & 129 & 4 & Very good \\
\hline & 12.00 & 67 & 139 & 132 & 113 & 4 & Very good \\
\hline & 14.00 & 140 & 109 & 178 & 142 & 4 & Very good \\
\hline & 16.00 & 143 & 152 & 93 & 129 & 4 & Very good \\
\hline \multirow{5}{*}{$\begin{array}{c}13 \\
\text { October } 2018\end{array}$} & 08.00 & 198 & 84 & 99 & 127 & 4 & Very good \\
\hline & 10.00 & 163 & 96 & 190 & 150 & 3 & Good \\
\hline & 12.00 & 164 & 104 & 132 & 133 & 4 & Very good \\
\hline & 14.00 & 190 & 92 & 142 & 141 & 4 & Very good \\
\hline & 16.00 & 99 & 106 & 152 & 119 & 4 & Very good \\
\hline \multirow{3}{*}{$\begin{array}{c}14 \\
\text { October } 2018\end{array}$} & 08.00 & 193 & 102 & 123 & 139 & 4 & Very good \\
\hline & 10.00 & 195 & 140 & 98 & 144 & 4 & Very good \\
\hline & 12.00 & 72 & 130 & 190 & 131 & 4 & Very good \\
\hline
\end{tabular}




\section{CONCLUSIONS}

From the results of the study, it can be concluded that there is a comparison of the quality of the connection from before and after the implementation of load balancing. This can be seen from the Tx / Rx monitoring results for each ISP and LAN indicating that the incoming throughput has the same average value, that is, the average obtained by the ISP-A (Rx) receiver is $34.75 \mathrm{Mbps}$, Rx ISP- B is $30.12 \mathrm{Mbps}$, Rx ISP-C is $7.17 \mathrm{Mbps}$ and the transmitter (Tx) LAN is $72.03 \mathrm{Mbps}$. The use of the Nth load balancing mechanism in each ISP is more optimal than before the use of load balancing Nth, and the acquisition of throughput that has used load balancing is balanced between the three ISP.

\section{REFERENCE}

[1] A. W. Syaputra and S. Assegaff, "Analisis Dan Implementasi Load Balancing Dengan Metode Nth Pada Jaringan Dinas Pendidikan Provinsi Jambi," J. Manaj. Sist. Inf., vol. 2, no. $4,2017$.

[2] I. Warman and A. Andrian, "Analisis Kinerja Load Balancing Dua Line Koneksi Dengan Metode Nth ( Studi Kasus : Laboratorium Teknik Informatika Institut Teknologi Padang )," Teknoif, vol. 5, no. 1, pp. 56-62, 2017.

[3] H. Nasser and T. Witono, "Analisis Algoritma Round Robin, Least Connection, Dan Ratio Pada Load Balancing Menggunakan Opnet Modeler," J. Inform., vol. 12, no. 1, 2016.

[4] S. F. Utami, Lindawati, "Optimalisasi Load Balancing Dua ISP untuk Manajemen Bandwidth Berbaa," Pros. Semin. Nas. Multi Disiplin Ilmu Call Pap., pp. 75-82, 2017.

[5] A. Syaifuddin, M. Yunus, and R. Sundari, "Hauru no ugoku shiro.," J. Teknol. Inf. Teor. Konsep, dan Implementasi, vol. 4, no. 2, pp. 60-74, 2005.

[6] S. A. Haris and H. Suhartono, "Menjaga Kestabilan Jaringan Load Balancing Nth Dengan Teknik Failover Pada PT . Jakarta Samudera Sentosa Jakarta," vol. 6, no. 1, pp. 49-60, 2018.

[7] R. Aldila, H. Azwar, and M. Diono, "Analisis Perbandingan Implementasi Load Balancing PCC ( Per connection classifier ), NTH dan ECMP ( Equal Eost Multi Path ),” J. Aksara Elem. Politek. Caltex Riau, vol. 5, no. 2, pp. 1-8, 2016.

[8] Y. A. Pranata, I. Fibriani, and S. B. Utomo, "Analisis Optimasi Kinerja Quality Of Service Pada Layanan Komunikasi Data Menggunakan NS - 2 di PT . PLN ( PERSERO ) Jember," Sinergi, vol. 20, no. 2, pp. 149-156, 2016.

[9] H. A. D.Rachmawan, D. Irwan, "Penerapan teknik load balancing pada web server lokal dengan metode nth menggunakan mikrotik," vol. 4, no. 2, pp. 98-108, 2016.

[10] E. Sumarno, "Implementasi metode load balancing dengan dua jalur," Implementasi Metod. Load Balanc. Dengan Dua Jalur, pp. 28-34, 2011. 